\title{
First registration of the harvest mouse (Micromys minutus Pallas) in Magadan Province, Russia
}

\author{
Nikolai E. Dokuchaev
}

\begin{abstract}
In summer 2003 the harvest mouse (Micromys minutus Pallas) for the first time was caught in the territory of Magadan Province. This species was not registered in Magadan Province and on the Sea of Okhotsk coast previously.
\end{abstract}

KEY WORDS: harvest mouse, Micromys minutus, distribution, Magadan Province, Sea of Okhotsk coast.

Nikolai E. Dokuchaev [dokuchaev@ibpn.kolyma.ru], Institute of biological problems of the North, Far East Branch of the Russian Academy of Sciences, ul. Portovaya 18, Magadan 685000, Russia.

\section{Первая находка мыши-малютки (Micromys minutus Pallas) в Магаданской области, Россия}

\begin{abstract}
Н.Е. Докучаев
РЕЗЮМЕ. Летом 2003 г. мышь-малютка впервые была отловлена на территории Магаданской области. Ранее этот вид не регистрировался в Магаданской области, равно как и на всем побережье Охотского моря.
\end{abstract}

КЛЮЧЕВЫЕ СЛОВА: мышь-малютка, Micromys minutus, распространение, Магаданская область, Охотское побережье.

The harvest mouse - Micromys minutus (Pallas, 1771) has vast range, extending from Great Britain and Pyrenees in the west, up to Japanese islands in the east. In eastern part of its range, within of Russia, the area of distribution of this species includes western slops of Sikhote-Alin Range, southern part of Khabarovsk Territory and Amur Province, and central and southern part of Yakutia (Tavrovsky et al., 1971; Revin et al., 1988; Revin, 1989; Kostenko, 2000). Recently the harvest mouse was caught in the north of Khabarovsk Territory in Maya River basin (Tiunov, 2003). In Sea of Okhotsk coast the harvest mouse earlier was never registered. In summer 2003 the harvest mouse was caught in Magadan Province for the first time (Fig. 1). The new sites $\left(59^{\circ} 44^{\prime}\right.$ $\mathrm{N} 149^{\circ} 52^{\prime} \mathrm{E}$ and $59^{\circ} 44^{\prime} \mathrm{N}, 150^{\circ} 51^{\prime} \mathrm{E}$ ) are situated approximately $900 \mathrm{~km}$ east from the previously known eastern margin of the species range, localities in Aldan and Maya river basins (Fig. 2). In July 10 and August 6, 2003 two harvest mice were caught by pitfalls with water in Dukcha River valley near Snezhnaya Dolina (Snow Valley) settlement located $20 \mathrm{~km}$ north from Magadan. Three more harvest mice were found among Sorex shrews preserved in formalin and handed to author by D.I. Berman. They were collected in July-September in Oira River mouth situated about $55 \mathrm{~km}$ to west from Magadan (Fig. 2).

Both harvest mice from Snezhnaya Dolina were mature males. Their testes were $7.5 \times 5.0$ and $8.2 \times 5.5$ $\mathrm{mm}$ in size, and in smears from epididymis of testes the mature spermatozoids were found. The measurements of harvest mice (first and second specimens respective- ly) are: body length 60 and $66 \mathrm{~mm}$, tail length 53 and 59 $\mathrm{mm}$, hind foot length 13.9 and $15.1 \mathrm{~mm}$, ear length 8.2 and $9.2 \mathrm{~mm}$, body weight 7.4 and $7.6 \mathrm{~g}$. Condilobasal skull length accordingly is 15.8 and $16.7 \mathrm{~mm}$, upper tooth row length 2.7 and $2.8 \mathrm{~mm}$, and low tooth row length 2.6 and $2.7 \mathrm{~mm}$. By the sizes and coloring, the harvest mouse specimens from Magadan Province can be attributed to the subspecies Micromys minutus ussuricus Barret-Hamilton, 1899 (Gromov \& Erbaeva, 1995). All specimens are kept in the collection of the Institute of Biological Problems of the North, Far East Branch of the Russian Academy of Sciences, Magadan (IBPN 6022-6026).

Dukcha River valley, were harvest mice were caught, is small. Its length is about $35 \mathrm{~km}$, and the valley is poorly developed. The slopes of mountains are covered with a larch forest (Larix cajanderi) with undergrowth from dwarf pine (Pinus pumila) and dwarf birch (Betula middendorfii). The flood-lands are engaged with woods from Populus suaveolens and Chosenia arbutifolia and willows. In area, were the harvest mice were caught, the valley is richly penetrated with small channels. There are open glades with bushes and motley grass in there. Among berry bushes the dog-roses (Rosa amblyotis, and $R$. acicularis) and honeysuckle (Lonicera edulis) are most usual. The small areas of flood-lands occupy by kitchen gardens with potatoes plantings.

Small mammals catching near Snezhnaya Dolina are conducted annually since 1980 . Also, since 1979, the stationary researches on small mammals in northern part of Kava-Tauy lowland in Chelomdzha River basin, west 


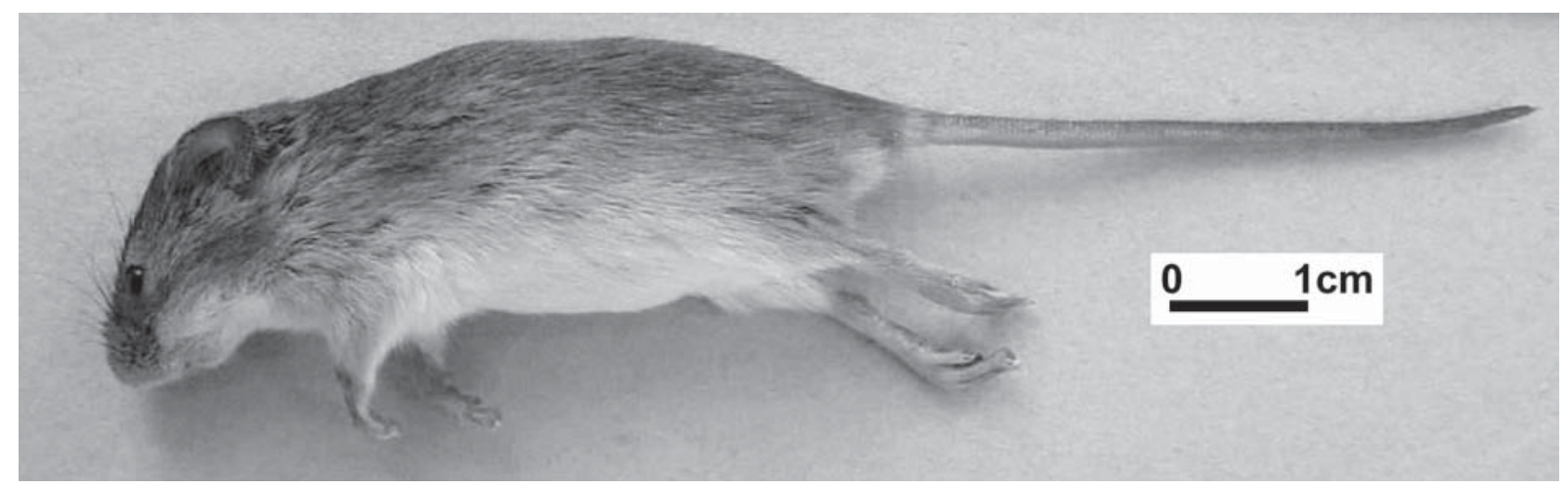

Figure 1. Harvest mouse (Micromys minutus) from Dukcha River valley near Snezhnaya Dolina settlement, $20 \mathrm{~km}$ north from Magadan, Magadan Province.

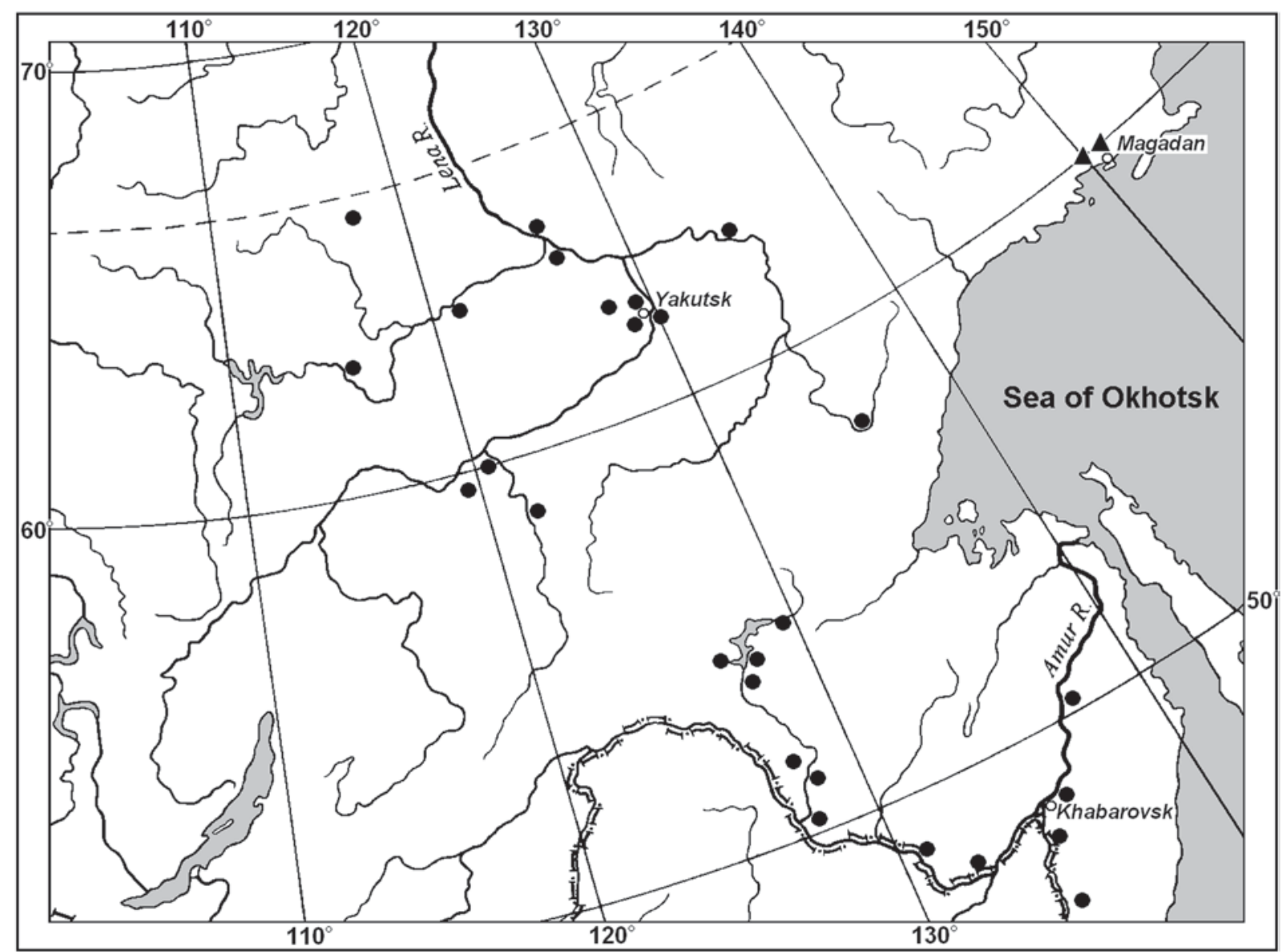

Figure 2. Distribution of harvest mouse (Micromys minutus) in Far East of Russia (circles), and new localities of this species in Magadan Province (triangles).

from Magadan, were carried out for more than ten years. The small mammals catching were carried out and in many other sites in the south of Magadan Province and northern part of Khabarovsk Territory (Yudin et al., 1976; Tiunov, 2003). During this time in northern part of Sea of Okhotsk coast there were caught some thousand small mammals. Despite so intensive catching, the harvest mouse was not registered there previously.
The casual delivery of the harvest mouse to Magadan Province, as it happened with the field mouse (Dokuchaev et al., 2001), is not likely. Most probably, this is natural range expansion of a species connected to the climatic changes marked in last ten years, including the territory of the southern part of Magadan Province (Ushakov, 2001). In particular, this author has shown that for last 30 years the average annual temperature of air has in- 
creased on $0.7^{\circ} \mathrm{C}$. The ice clearing dates in spring were displaced (in the party earlier) for seven days and on the same term, but the later dates of occurrence of floating ice in autumn in Nagaevo Bay at Magadan. The parameters of maximal ice conditions in the Sea of Okhotsk have decreased on $6 \%$. The penetration of the harvest mouse on the Sea of Okhotsk coast obviously has taken place from Yakutia along of Yudoma-Maya and Urak river valleys. Before the same way of penetration to the northwest part of Sea of Okhotsk coast from Yakutia was observed for Sorex roboratus Hollister, 1913 (Dokuchaev, 1998). The catching of the harvest mouse in Magadan Province demonstrates that the animals sensitively react to changes in an environment, demonstrating thus amazing opportunities to moving.

ACKNOWLEDGEMENTS. I thank to A. Zinkin and K. Starenchenko for their help in the small mammals collecting.

\section{References}

Gromov I.M. \& Erbaeva M.A. 1995. [The Mammals of Russia and Adjacent Territories. Lagomorphs and Rodents]. Sankt Peterburg: Zoologicheskii Institut RAN. 522 p. [in Russian].

Dokuchaev N.E. 1998. [The Shrews of North-East Asia and Neighboring Territories (Biology, Systematics, Quater- nary History)]. Dissertatsiya na Soiskanie Uchenoi Stepeni Doktora Biologicheskikh Nauk. Vladivostok. 63 p. [in Russian].

Dokuchaev N.E., Pospekhov V.V. \& Lazutkin A.N. 2001. [The undesirable introduction of field mouse to Magadan Province] // Kolymskie Vesti. No.14. P.19-20 [in Russian].

Kostenko V.A. 2000. [Rodents (Rodentia) of the Russian Far East]. Vladivostok: Dal'nauka. 210 p. [in Russian].

Revin Yu.V. 1989. [The Mammals of Southern Yakutia]. Novosibirsk: Nauka. 321 p. [in Russian].

Revin Yu.V., Safronov V.M., Volpert Ya.L. \& Popov A.L. 1988. [The Ecology and Population Dynamics of Mammals in Verkhoyansk Area]. Novosibirsk: Nauka. 200 p. [in Russian].

Tavrovski V.A., Egorov O.V., Krivosheev V.G., Popov M.V. \& Labutin Yu.V. 1971. [The Mammals of Yakutia]. Moskva: Nauka. 660 p. [in Russian].

Tiunov M.P. 2003. [New data on distribution of small mammals in the Sea of Okhotsk region and adjacent territories] // Zoologicheskii Zhurnal. T.82. No.1. P.123-125 [in Russian].

Ushakov M.V. 2001. [Some signals of recent global warming in Magadan Province and Sea of Okhotsk] // Kolymskie Vesti. No.12. P.49-50 [in Russian].

Yudin B.S., Krivosheev V.G. \& Belyaev V.G. 1976. [The Small Mammals of the North of Far East]. Novosibirsk: Nauka. 270 p. [in Russian]. 